\title{
Effect of Self Care Education on Quality of Life and Body Image among Burned Patients
}

\author{
Fathya Rady Magbool ${ }^{1}$, Ghona Abd El-Nasser Ali ${ }^{2}$, Attyiat Hassan Hussein ${ }^{3}$ \& Mohamed Eloteify $\mathbf{J r}^{4}$ \\ 1. Fellow of Medical-Surgical Nursing, Assuit University Hospitals, Egypt. \\ 2. Professor of Medical-Surgical Nursing, Faculty of Nursing, Sohag University, Egypt. \\ 3. Assistant Professor of Medical-Surgical Nursing, Faculty of Nursing, Assuit University, Egypt. \\ 4. Lecturer of Plastic surgery \& Burn, Faculty of Medicine, Aswan University
}

\begin{abstract}
:
Burns have a negative effect on quality of life of patients and can impair their physiological, psychological, social and spiritual well-being. Aim of the study: to evaluate the effect of self-care education on quality of life and body image among burned patients. Research design: Quasi-experimental design. Setting: The study was conducted in burn department and outpatient's burn clinic, at Assiut Burn Center, Assiut city. Sample: Sixty male and female adult patients their age (18-65) years, diagnosed with first, second and third degree of burn. Percentage of burn from $18-45 \%$. Tools: three tools used in this study: Patient assessment sheet, it included (personal and medical data), Burn Specific Health Scale-Brief (BSHS-B), and self-care education booklet. Results: Less than half of sample was in the age group of 36-55 years with mean $42.08 \pm 13.415$ yrs. There was a highly significant statistical difference for patients' quality of life and body image before and after self-care education. Conclusion: Self-care education was effective on improving quality of life and body image among burned patients. Recommendations: Teaching booklet for burned patients to improve quality of life should be available in burn departments.
\end{abstract}

Keywords: Burn, Body image, Self-Care Education \& Quality of Life.

\section{Introduction:}

Burns are a common type of trauma across the world. The world Health Organization (WHO) estimates that annually about (11) million people suffer a burn that requires medical attention, while there are 180,000 burn deaths worldwide. The WHO classifies burn as the greatest burden in terms of morbidity including disability, disfigurement, stigma and rejection (WHO, 2018).

Burns are traumatic injuries caused by coagulative destruction of the skin and are usually caused by thermal damage (heat and cold); chemicals, electricity and radiation may also damage tissues in similar ways (Helen et al., 2017).

Burn injuries have negative influence on quality of life of patients and can disturb their physiological, psychological, social and spiritual well-being (Ardebili et al., 2016)

According to Assiut Burn Center record in 2019 the number of patient admitted to the center 210 patient (Hospital record, 2019)

The problems associated with the quality of life are severe, as the patient and their family experience life with new physical problems and challenges in their relationships (Hinkle \& Cheever, 2014). Thus, promotion of the quality of life, and in turn, the promotion of health is considered as inseparable parts of socioeconomic development (Pishnamazi et al., 2011)

In general, the concept of quality of life encompasses a wide and multidimensional assessment of areas related to physical, psychological and social aspects. (Stavrou et al., 2014) In burned patients, HRQOL defined as the health status related to responsiveness and adaptation to changes resulting from trauma, considering the individual, family and social aspects. (Wasiak et al., 2017)

The evaluation of the quality of life can assist the burn team in determining the needs of burned patients and identifying the domains of quality of life affected by burns. Given that nurses have a maximum contact with patients and relate to patients from the very early moments after the burn up to years after that, undertake the emotional support provide to the patient and their family, and monitor the treatments (Elsherbiny et al., 2017).

Nurses have an active role in assessing the post-burn quality of life. If required, they should evaluate the mental and psychological status of the burned patients in terms of mental disorder and body image. They should also determine the specific educational needs of the patient and their family for self-care and house care. In addition, they can aid the rehabilitation team in assisting the patient to accept their current situation, develop self-confidence and not depend on others, and eventually return to the family environment and the society (Mirzabeygi \& Givry, 2011)

Information on the health of patients suffering from burns is generally measured by the index of healthrelated quality of life (Müller et al., 2017). 
The advances in the field of burn treatment resulted in increased survival of burn patients, which led to increased attention to the issues associated with the quality of life. The assessment of the quality of life and the associated factors might help in identifying the needs of affected patients and designing suitable therapeutic and supportive programs (Jafaryparvar et al., 2018).

\section{Significant of study:}

From the researcher's experience, it has been observed that burned patients can expose to many problems and complications as a result of burn injury which effect on quality of life and body image. The patients with burn needed special self-care education to improve the patients' outcomes. This study will be conduct to provide patients with self-care education that provide information on how to stay as healthy as possible and improve quality of life.

\section{Aim of the Study:}

To evaluate the effect of self-care education on quality of life and body image among burned patients.

Research hypothesis:

1. Quality of life among burned patients will be improved after conducting the self-care education.

2. Body image among burned patients will be improved after conducting the self-care education.

\section{Materials and Methods: \\ Research design:}

Quasi-experimental design was used to achieve the aim of the present study.

\section{Setting:}

The study was conducted at burn department and outpatients' burn clinic at Assiut Burn Center, Assiut city. It is assumed that the study should have taken place at Assiut University, but the burn department at Assiut University Hospital is closed for maintenance, the data collection was conducted at the Assiut Burns Center.

\section{Subjects:}

Sixty adult patients with diagnosed with first, second and third degree of burn, their age (18-65) yrs. Both gender (male \& female), old, recent and healed burn, and burn percentage from $18-45 \%$.

\section{Sample size:}

The power analysis to estimate the sample size was performed based on the result of a pilot study. Assuming power of $0.80 \%$ and a 0.05 (one-sided equivalence test), a total sample size of 50 participants is required. The eligible patients were invited to participate after the assessment whether they meet all of the inclusion criteria $n=60$. The nonrandomized study sample involved 60 patients.

Tools of data collection:

Tool: (I): Patient assessment sheet: it included two parts:

Part (A): Personal data as: Age, gender, marital status, residential district, educational level and employment status.

Part (B): Medical history data such as: Medical diagnosis, burn percent and depth, total body burned area, cause of burn, duration of injury and number of surgeries.

Tool (II): Burn Specific Health Scale-Brief (BSHSB): (Kildal et al., 2001 \& Pishnamazi et al., 2013).

Burn Specific Health Scale-Brief (BSHS-B) had 40 items covering nine well-defined domains including simple abilities (questions from 1 to 3 ); hand function (questions from 4 to 8), affect (questions from 9 to 15), body image (questions from 16 to 19), interpersonal relationship (questions from 20 to 23), sexuality (questions from 24 to 26), heat sensitivity (questions from 27 to 31 ), treatment regimen (questions from 32 to 36 ), and work (questions from 37 to 40)

Scoring system:

Responses were rated on a 5-point scale from 0 (extremely) to 4 (none/not at all) for each of the 40 items and patients were asked to select the best answer. Mean scores were calculated for each of the domains. This final score reflected an alteration of the QOL. A higher mean score indicated a more positive evaluation of function and a higher QOL. The total score ranges from 0 to 160 . Less than $80=$ low (-ve) quality of life (QOL), 80 and more $=$ high (+ve) quality of life (QOL).

Tool III: Self-care education booklet:

The content of booklet was developed in a simple Arabic language by the researcher based on patients' assessment needs, literature review, researcher experience and opinion of the medical and nursing expertise to evaluate effect of self-care education on quality of life and body image among burned patients.

It consists of three parts:-

Part I: Burn complications such as contracture and itching. Effect of sun on burn area, the patient must be far from the exposure of sun rays and cover the burned area and walk in the shadow.

Part II: How to deal and adaptation with complications of burn: it includes the following:

- Wearing gloves: the gloves must be wearing to protect burned area and help in healing.

- Keep the burned area clean: the patient must be taken bath every day and pour the water gently on burned area continuously. 
- Keep the burned area moist: by used cream for keep the skin moist.

- Range of Motion Exercises: exercises help and keeping the muscles and joints of the burned limbs flexible. ROM exercises were needed to prevent joint stiffness and contractures over the affected joints.

-Splinting: Splinting was helping maintain anticontracture positioning particularly for those patients experiencing a great deal of pain. Splinting was very important in the prevention of contractures and ensuring the best possible functional gains for the burn patient.

-Fluids: the patient must be taken a lot of fluids especially water

\section{Administrative Design:}

The researchers acquired official approval from the director of the Assiut Burn Center, Assiut city and the head nurse of burn unit.

\section{Pilot Study:}

It was conducted on $10 \%$ of subjects (6 patients) in the selected settings for testing clarity, arrangement, applicability of tool, and time needed. The required modifications were made. Those patients who were involved in the pilot study were included in the study.

\section{Ethical Considerations:}

Research proposal was accepted by Ethical Committee within the College of Nursing. There is no hazard for study subject during application of the research. The study was complying with ethical principles in clinical research. Informed consent acquired from patients or guidance that who are willing to participate in the study, after explaining the aim of the study. Study subject has the right to refuse to participate or withdraw from the study with no rational any time and privacy have been taken into consideration for the collection of data.

\section{Validity and reliability:}

The tool $(1,2 \& 3)$ was tested for content validity by 5 experts in academic medical and nursing staff at Assiut University. Modifications were done accordingly, and then the tools were designed in its final format and test-retest of reliability for tool (1, 2 \& 3) was done by Cronbach's alpha 0.80 .

\section{Procedure:}

The researchers initiated data collection, once permission was granted to proceed with the proposed study. The researchers interviewed the patients to fulfill their personal data, tool (1) Part (A) and it consists of (6) items. As well as filling tool (1) Part (B) of medical data and it consists of (5) items. The aim of the study was explained to the patients and informed consent was obtained from the patients. After that, the researchers conducted a face-to-face interview with the patients to evaluate their information about the self-care for their quality of life, the impression on his body image and how their lifestyle and during this phase conducted a pre- test for the patients'.

The researchers visited the burn unit two days a week from 9 am to 12 noon and alternately held individual interviews with each patient separately. Face-to-face educational sessions that lasted between 15-20 minutes for each patient to present information and correct misconceptions, and the interviews consisted of oral instructions and explanatory videos and presenting the contents that was prepared in advance and includes a comprehensive coverage of what the Burn Specific Health Scale-Brief (BSHS-B) contains. The researchers conducted a post-test 2 months after application of self-care education, as each patient was interviewed individually to maintain the privacy of the information that he would answer to ensure that the instructions were cleared, the exercises were implemented, and the patient's ability to adapt to the new lifestyle, which he was trained on through the educational self-care instructions.

\section{Statistical design:}

The data obtained had reviewed, prepared for computer entry, coded, analyzed and tabulated. Descriptive statistics (frequencies and percentages, means and standard deviation, i.e.) were done using computer program (SPSS) version (20). Independent sample t-test, ANOVA and, Chi-square tests used in the relationship between both groups'. It's considered significant when P. value was less than (0.05). 


\section{Results:}

Table (1): Distribution of study sample related to personal data of patients $(n=60)$ :

\begin{tabular}{|c|c|c|}
\hline$\overline{I t e m s}$ & No. & $\%$ \\
\hline \multicolumn{3}{|l|}{ 1. Gender: } \\
\hline Male & 31 & 51.7 \\
\hline Female & 29 & 48.3 \\
\hline \multicolumn{3}{|l|}{ 2. Address: } \\
\hline Urban & 17 & 28.3 \\
\hline Rural & 43 & 71.7 \\
\hline \multicolumn{3}{|l|}{ 3. Age: } \\
\hline $18-35$ & 19 & 31.7 \\
\hline $36-55$ & 29 & 48.3 \\
\hline $56-65$ & 12 & 20.0 \\
\hline Mean \pm SD & $42.0833 \pm 13.41551$ & \\
\hline \multicolumn{3}{|l|}{ 4. Marital status: } \\
\hline Single & 9 & 15.0 \\
\hline Married & 44 & 73.3 \\
\hline Widowed & 5 & 8.3 \\
\hline Divorced & 2 & 3.3 \\
\hline \multicolumn{3}{|l|}{ 5. Education Level: } \\
\hline Illiterate & 10 & 16.7 \\
\hline Read and write & 12 & 20.0 \\
\hline Secondary & 26 & 43.3 \\
\hline Have a university degree & 12 & 20.0 \\
\hline \multicolumn{3}{|l|}{ 6. Job } \\
\hline Employee & 15 & 25.0 \\
\hline Retired & 5 & 8.3 \\
\hline Housewife & 19 & 31.7 \\
\hline Literal & 11 & 18.3 \\
\hline Free work & 4 & 6.7 \\
\hline Student & 5 & 8.3 \\
\hline No work & 1 & 1.7 \\
\hline
\end{tabular}

Table (2): Distribution of study sample related to medical history $(n=60)$ :

\begin{tabular}{|l|c|c|}
\hline \multicolumn{1}{|c|}{ Items } & No. & \% \\
\hline 1. Duration of injury: & & 50.0 \\
\hline$<1$ year & 30 & 10 \\
\hline year & 12 & 20.0 \\
\hline 2 years & 4 & 6.7 \\
\hline years & 4 & 6.7 \\
\hline$>$ 3years & & \\
\hline 2. Number of Plastic Surgery : & 11 & 18.3 \\
\hline 0 & 30 & 50.0 \\
\hline 1 & 16 & 26.7 \\
\hline 2 & 2 & 3.3 \\
\hline 3 & 1 & 1.7 \\
\hline 5 & & \\
\hline 3. TBSA & 7 & 11.7 \\
\hline $10-19 \%$ & 38 & 63.3 \\
\hline $20-29 \%$ & 9 & 15.0 \\
\hline $30-39 \%$ & 6 & 10.0 \\
\hline $40-45 \%$ & \multicolumn{2}{|c|}{$25.4000 \pm 7.33046$} \\
\hline Mean \pm SD & \multicolumn{2}{|c|}{} \\
\hline
\end{tabular}




\begin{tabular}{|l|c|c|}
\hline \multicolumn{1}{c|}{ Items } & No. & \% \\
\hline 4. Burn Site: & & 1.7 \\
\hline Head & 1 & 30.0 \\
\hline Neck & 18 & 43.3 \\
\hline Chest & 26 & 35.0 \\
\hline Abdomen & 21 & 15.0 \\
\hline Left arm & 9 & 40.0 \\
\hline Right arm & 24 & 10.0 \\
\hline Buttocks & 6 & 15.0 \\
\hline Left leg & 9 & 23.3 \\
\hline Right leg & 14 & 0.0 \\
\hline Genitalia & 0 & \\
\hline
\end{tabular}

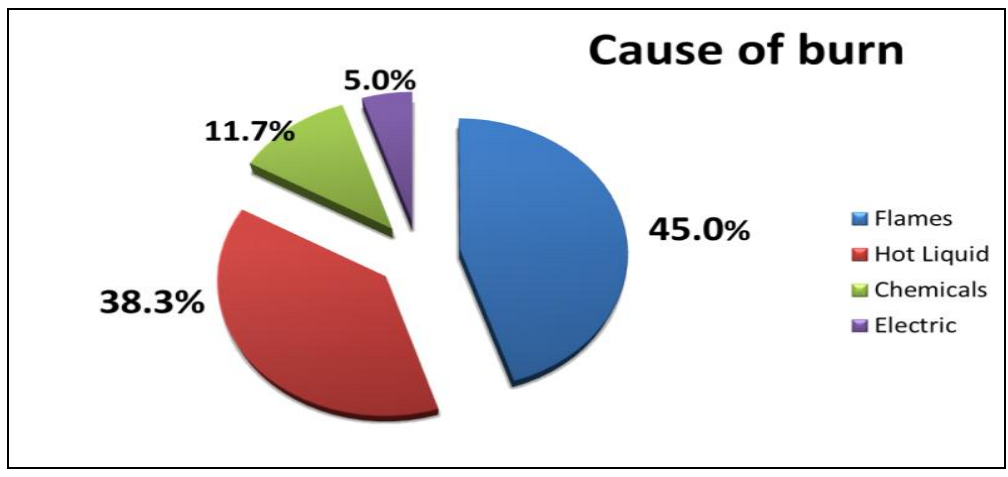

Figure (1): Distribution of study sample related to cause of burn (n=60)

Table (3): Comparison between pre and post self-care education according to QOL Domains ( $\mathrm{n}=60)$ :

\begin{tabular}{|c|c|c|c|c|c|}
\hline \multirow[t]{2}{*}{ QOL Domains } & \multicolumn{2}{|c|}{ low (-ve) QOL } & \multicolumn{2}{|c|}{ High (+ve) QOL } & \multirow{2}{*}{ p-value } \\
\hline & No. & $\%$ & No. & $\%$ & \\
\hline $\begin{array}{l}\text { 1. Simple capabilities: } \\
\text { Pre }\end{array}$ & 20 & 33.3 & 40 & 66.7 & \multirow{2}{*}{$0.346 \mathrm{~ns}$} \\
\hline Post & 17 & 28.3 & 43 & 71.7 & \\
\hline $\begin{array}{l}\text { 2. Hand function: } \\
\text { Pre }\end{array}$ & 58 & 96.7 & 2 & 3.3 & \multirow{2}{*}{$\begin{array}{c}0.0001 \\
* * *\end{array}$} \\
\hline Post & 20 & 33.3 & 40 & 66.7 & \\
\hline $\begin{array}{l}\text { 3. How affect burn: } \\
\text { Pre }\end{array}$ & 42 & 70.0 & 18 & 30 & \multirow{2}{*}{$0.0001 * * *$} \\
\hline Post & 20 & 33.3 & 40 & 66.7 & \\
\hline $\begin{array}{l}\text { 4. Body Image: } \\
\text { Pre }\end{array}$ & 44 & 73.3 & 16 & 26.7 & \multirow{2}{*}{$0.0001 * * *$} \\
\hline Post & 16 & 26.7 & 44 & 73.3 & \\
\hline $\begin{array}{l}\text { 5. Health: } \\
\text { Pre }\end{array}$ & 29 & 48.3 & 31 & 51.7 & \multirow[t]{2}{*}{$0.0001 * * *$} \\
\hline Post & 5 & 8.3 & 55 & 91.7 & \\
\hline $\begin{array}{ll}\text { 6. Interpersonal: relations } \\
\text { Pre }\end{array}$ & 56 & 93.3 & 4 & 6.7 & \multirow[t]{2}{*}{$0.048 \mathrm{~ns}$} \\
\hline Post & 11 & 18.3 & 49 & 81.7 & \\
\hline $\begin{array}{l}\text { 7. Sexual status: } \\
\text { Pre }\end{array}$ & 40 & 66.7 & 20 & 33.3 & \multirow[t]{2}{*}{$0.422 \mathrm{~ns}$} \\
\hline Post & 18 & 30.0 & 42 & 70.0 & \\
\hline $\begin{array}{ll}\text { 8. } & \text { Treatment: } \\
\text { Pre }\end{array}$ & 18 & 30.0 & 42 & 70.0 & \multirow[t]{2}{*}{$0.002 *$} \\
\hline Post & 5 & 8.3 & 55 & 91.7 & \\
\hline $\begin{array}{l}\text { 9. Work: } \\
\text { Pre }\end{array}$ & 17 & 28.3 & 43 & 71.7 & \multirow[t]{2}{*}{0.500} \\
\hline Post & 18 & 30.0 & 42 & 70.0 & \\
\hline
\end{tabular}


Table (4) Comparison between pre and post self-care education according to QOL $(n=60)$ :

\begin{tabular}{|c|c|c|c|c|c|}
\hline \multirow[t]{2}{*}{ QOL } & \multicolumn{2}{|c|}{ Pre } & \multicolumn{2}{|c|}{ Post } & \multirow{2}{*}{ p-value } \\
\hline & No. & $\%$ & No. & $\%$ & \\
\hline High (+ve) QOL & 21 & 35.0 & 48 & 80.0 & \multirow{3}{*}{$\begin{array}{c}0.0001 \\
* * *\end{array}$} \\
\hline low (-ve) QOL & 39 & 65.0 & 12 & 20.0 & \\
\hline Total & 60 & 100.0 & 60 & 100.0 & \\
\hline
\end{tabular}

Table (5): Comparison between mean QOL score pre and post self-care education $(\mathrm{n}=60)$ :

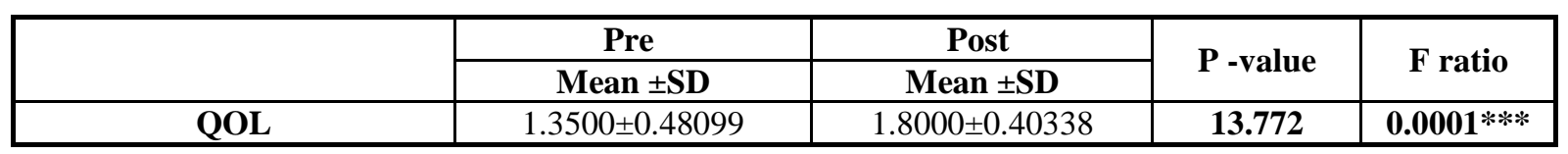

Independent Samples Test $\quad$ *** highly significant

Table (6): Relationship between personal data and QOL Post self-care education $(n=60)$ :

\begin{tabular}{|c|c|c|c|c|c|}
\hline \multirow{3}{*}{ Items } & \multicolumn{4}{|c|}{ QOL Post self-care education } & \multirow{3}{*}{$P$ value } \\
\hline & \multicolumn{2}{|c|}{ Low ( -ve) QOL (12) } & \multicolumn{2}{|c|}{ High (+ve) QOL (48) } & \\
\hline & N. & $(\%)$ & N. & $(\%)$ & \\
\hline \multicolumn{6}{|l|}{ Gender: } \\
\hline Male & 7 & 11.7 & 24 & 40.0 & \multirow[t]{2}{*}{$0.424 \mathrm{~ns}$} \\
\hline Female & 5 & 8.3 & 24 & 40.0 & \\
\hline \multicolumn{6}{|l|}{ Address: } \\
\hline Urban & 4 & 6.7 & 13 & 21.7 & \multirow[t]{2}{*}{$0.459 \mathrm{~ns}$} \\
\hline Rural & 8 & 13.3 & 35 & 58.3 & \\
\hline \multicolumn{6}{|l|}{ Age: } \\
\hline $18-35$ & 4 & 6.7 & 15 & 25.0 & \multirow[t]{3}{*}{$0.360 \mathrm{~ns}$} \\
\hline $36-55$ & 4 & 6.7 & 25 & 41.7 & \\
\hline $55-65$ & 4 & 6.7 & 8 & 13.3 & \\
\hline \multicolumn{6}{|l|}{ Marital status: } \\
\hline Single & 1 & 1.7 & 8 & 13.3 & \multirow{4}{*}{$\begin{array}{c}0.532 \\
n s\end{array}$} \\
\hline Married & 9 & 15.0 & 35 & 58.3 & \\
\hline Widowed & 2 & 3.3 & 3 & 5.0 & \\
\hline Divorced & 0 & 0.0 & 2 & 3.3 & \\
\hline \multicolumn{6}{|l|}{ Education Level: } \\
\hline Illiterate & 3 & 5.0 & 7 & 11.7 & \multirow{4}{*}{$\begin{array}{c}0.597 \\
\text { ns }\end{array}$} \\
\hline Read and write & 1 & 1.7 & 11 & 18.3 & \\
\hline Secondary & 6 & 10.0 & 20 & 33.3 & \\
\hline University degree & 2 & 3.3 & 10 & 16.7 & \\
\hline \multicolumn{6}{|l|}{ Job: } \\
\hline Employee & 5 & 8.3 & 10 & 16.7 & \multirow[t]{7}{*}{$0.335 \mathrm{~ns}$} \\
\hline Retired & 2 & 3.3 & 3 & 5.0 & \\
\hline House wife & 2 & 3.3 & 17 & 28.3 & \\
\hline Literal & 3 & 5.0 & 8 & 13.3 & \\
\hline Free work & 0 & & 4 & 6.7 & \\
\hline Student & 0 & & 5 & 8.3 & \\
\hline No Work & 0 & & 1 & 1.7 & \\
\hline
\end{tabular}


Table (7): Relationship between Medical history and QOL Post self-care education $(\mathrm{n}=60)$ :

\begin{tabular}{|c|c|c|c|c|c|}
\hline \multirow{3}{*}{$\begin{array}{r}\text { Items } \\
\text { Duration of injury: }\end{array}$} & \multicolumn{4}{|c|}{ QOL Post self-care education } & \multirow{3}{*}{$P$ value } \\
\hline & \multicolumn{2}{|c|}{ Low ( -ve) QOL (12) } & \multicolumn{2}{|c|}{ High (+ve) QOL (48) } & \\
\hline & $\mathbf{N}$ & $\%$ & $\mathbf{N}$ & $\%$ & \\
\hline$<1$ year & 5 & 8.3 & 25 & 41.7 & \multirow{5}{*}{$0.626 \mathrm{~ns}$} \\
\hline 1 year & 2 & 3.3 & 8 & 13.3 & \\
\hline 2 years & 4 & 6.7 & 8 & 13.3 & \\
\hline 3 years & 1 & 1.7 & 3 & 5.0 & \\
\hline >3years & 0 & 0.0 & 4 & 6.7 & \\
\hline \multicolumn{6}{|c|}{ Number of Plastic Surgery : } \\
\hline 0 & 2 & 3.3 & 9 & 15.0 & \multirow{5}{*}{$0.123 \mathrm{~ns}$} \\
\hline 1 & 8 & 13.3 & 22 & 36.7 & \\
\hline 2 & 1 & 1.7 & 15 & 25.0 & \\
\hline 3 & 0 & 0.0 & 2 & 3.3 & \\
\hline 5 & 1 & 1.7 & 0 & 0.0 & \\
\hline \multicolumn{6}{|l|}{ TBSA: } \\
\hline $10-19 \%$ & 1 & 1.7 & 6 & 10.0 & \multirow{4}{*}{$0.895 \mathrm{~ns}$} \\
\hline $20-29 \%$ & 10 & 16.7 & 28 & 46.7 & \\
\hline $30-39 \%$ & 0 & 0.0 & 9 & 15.0 & \\
\hline $40-45 \%$ & 1 & 1.7 & 5 & 8.3 & \\
\hline \multicolumn{6}{|l|}{ Burn Site: } \\
\hline Head & 0 & 0.0 & 1 & 1.7 & \multirow[t]{10}{*}{$0.582 \mathrm{~ns}$} \\
\hline Neck & 3 & 5.0 & 15 & 25.0 & \\
\hline Chest & 6 & 10.0 & 20 & 33.3 & \\
\hline Abdomen & 3 & 5.0 & 18 & 30.0 & \\
\hline Left arm & 2 & 3.3 & 7 & 11.7 & \\
\hline Right arm & 4 & 6.7 & 20 & 33.3 & \\
\hline Buttocks & 3 & 5.0 & 3 & 5.0 & \\
\hline Left leg & 3 & 5.0 & 6 & 10.0 & \\
\hline Right leg & 2 & 3.3 & 12 & 20.0 & \\
\hline Genitalia & 0 & 0.0 & 0 & 0.0 & \\
\hline
\end{tabular}

Chi-Square Tests ns= non -significant

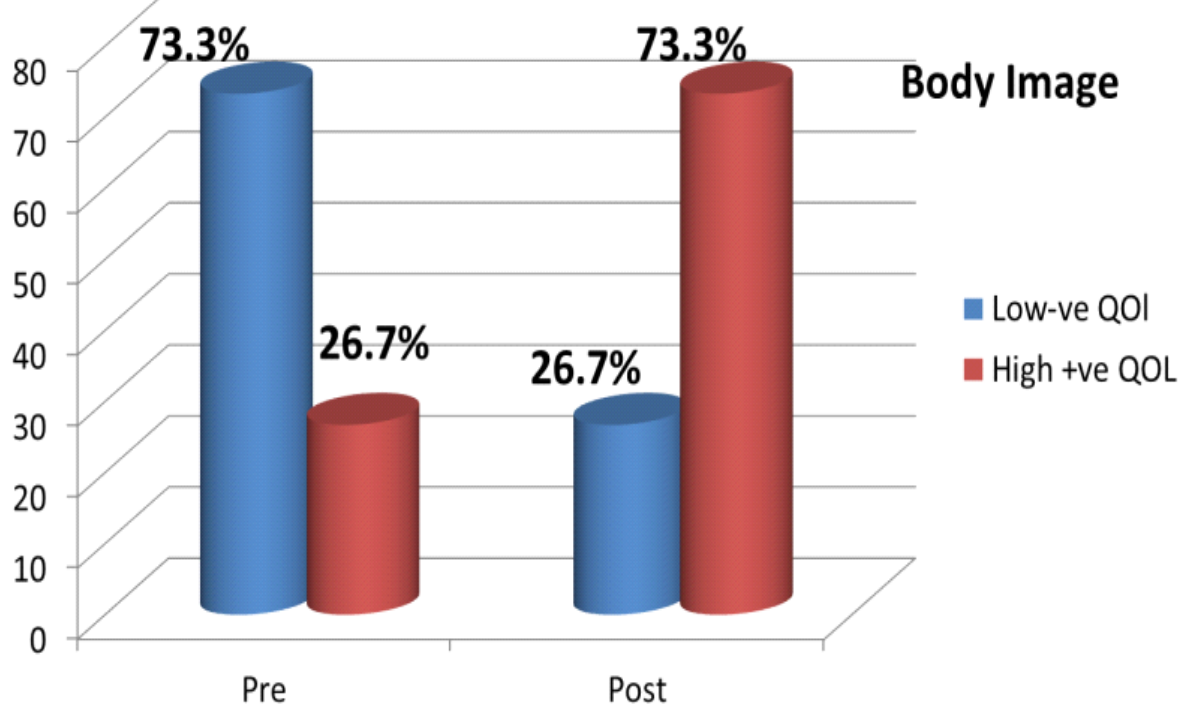

Fig. (2): Comparison between pre and post self-care education regarding to Body image $(\mathrm{n}=60)$ 
Table (1): Shows that more than half of the studied patients $(51.7 \%)$ were males, most of them $(71.7 \%)$ lived in rural areas and less than half $(48.3 \%)$ of them were in the age group of 36-55 years with mean $42.08 \pm 13$. 415 yrs., about three-quarters of them $(73.3 \%)$ were married, the less than half of them $(43.3 \%)$ have a secondary education, According to occupation, the highest percentage of patients were house wife (31.7).

Table (2): Illustrates that; half of the studied patients (50\%) had suffered from the burn for less than a year and had undergone only one plastic surgery, according to TBSA most of the patients from 20$29 \%$ with mean $25.4000 \pm 7.33046$, regarding to burn site less than half of them had burn in neck, chest, abdomen, and right arm $(30.0,43.0,35.0,40.0)$ respectively.

Fig. (1): Reflects that; the most common cause of burn according to studied patients was flames then hot liquid (45.0\%-38.3\%) respectively.

Table (3): Reflects that; there was an increase in the number of patients who had high +ve QOL post selfcare education application comparing to their number pre self-care education application in most of domains.

Table (4): founds that: there was a highly significant statistical difference between pre, post self-care education applications regarding QOL in all domains.

Table (5): Shows that: there was a highly significant statistical difference between pre, and post mean score toward QOL in all domains.

Table (6): Reflects that there was no significant statistical difference between personal data and QOL Post self-care education.

Table (7): Shows that there was no significant statistical difference between medical data and QOL Post self-care education.

Fig. (2): Reflects that there was an increase in the number of patients who had high (+ve) body image post application of self-care education comparing to their number pre application of self-care education.

\section{Discussion:}

Discharge of burned patient from the hospital does not mean the end of treatment for a patient with burns, but beginning of a new period of care. In fact, the care responsibility of the treatment team is transferred to the patient and family which may be associated with new problems (Coleman et al., 2014).

The present study revealed that more than half of the studied patients were males, most of them lived in rural areas and less than half of them were in the age group of 36-55 years with mean $42.08 \pm 13.415$ yrs., about three-quarters of them were married, the less than half of them have a secondary education, according to occupation, the highest percentage of patients were employed. These results were agree with study conducted by (Seyedoshohadaee, et al., 2019) who studied the effect of training course on the body image of the burned patients and founded that, the mean age in men and women was $37 \pm 10.3$ and $37.6 \pm 9$, respectively.

Another study done by Abd Elalem et al., (2018) and revealed that more than half of the study patients coming from rural areas, house wife and had secondary education, Zhang et al., (2019) added that majority of patients were male. This result on the contrary with study done by Faisal et al., (2015) who mention that the majority of burned patient were female, and this result was related to the female is more contact with fire at home than male.

According to the duration of burn injury, the present study illustrates that, half of the studied patients had suffered from the burn for less than a year and had undergone only one plastic surgery. In this respect the present study shows the chest, abdomen and limb were the most frequently areas burn site in addition to face, neck and back. This result was convenient with results of study done by Diane et al., (2017).

Regarding to burn site the present study revealed that, less than half of them had burn in neck, chest, abdomen and right arm and TBSA most of the patients were from $20-29 \%$ with mean $25.4 \pm 7.3$ these results were convenient with Abd Elalem et al., (2018), also Zorita et al. (2016) who mention that the mean burn size was $21 \% \pm 17.10 \%$ of TBSA, and this may be due to that the majority of the study respondents were female housewifes and had the accidental burn at their home. On the same line and according to the causes of burn, the current study shown that the most common causes of burn injury was flames and hot liquids. These results were a compatible with the study results was done by Hashemi et al., (2014) about the effect of self-care Orem program on the QOl of burn patients and found that the flame was the main cause of burn.

According to the quality of life, the current study found that, there was a highly significant statistical difference between pre, post self-care education applications regarding QOL in all domains. This result were consistent with Abd Elalem et al., (2018) who reported that the mean QOL score was significantly lower in pre intervention but in post intervention overall mean score increased with a highly statistically significant difference $\mathrm{p}<.001$. 
The same results were found in study done by Li et al., (2016). While, the results of our study were contradict with study done by Roh et al., (2010) entitled effects of rehabilitation program on depression, and burn-specific health in burned survivors, who reported that the impact of rehabilitation program on the QOL of burn patients is not substantial, and the study recommended that further studies with the use of the program should be done with more samples and in a longer duration.

In the same context, the present study also, found that there was a significant relation between the patients' body image and QOL, which appeared in the increase in the number of patients with a had high level of QOL after intervention when compared to their number before program application. This is in line with findings.

Seyedoshohadaee et al., (2019) who found that, there was a significant difference between the mean scores of body image and QOL before and after interventions.

In relation between personal date and QOL post intervention. The current study revealed that there was no significant statistical difference between personal data and QOL post self-care education. This result consistent with Orwelius et al., (2013) who reported that, factors other than the burn itself, such as mainly joblessness and pre-existing disease were most vital for the long term HRQoL experience in these patients. Pishnamazy et al., (2012) also founded that, the burn patients are confronted with many difficulties which effect on their QOL especially the psychological aspects.

These results were contradict with results found by Echevarría-Guanilo et al., (2016); Ozdemir \& Saritas (2018) who reported that, the aspects of QOL were influenced by gender, level of education, occupation, TBSA, and visibility of scars, with statistically significant correlations were found. And in my opinion, there is no difference with regard to demographic data and the quality of life between burned patients, due to the fact that burns are devastating injuries and effect on all groups, whether they are female or male, rural or urban, and all educational groups.

The result of current study revealed that, there was no significant statistical difference between total body surface area and QOL. This result contradict with the result of study conducted by Shahid et al., (2018) who found that the depth and extent \%TBSA burn and post burn period have negative impact on health related quality of life scores. Also, the present study show improvement in QOL as related to duration the injury especially in duration less than one year. This result consistent with study result done by
Echevarría-Guanilo et al., (2016) and who observe that an improvement in health-related to quality of life during the first year. Ozdemir \& Saritas (2018) stated that nurses who provide health service are responsible for maximizing the quality of life.

Shahid et al., (2018) added that, in order to achieve optimal outcomes of burn sustained patients' health care system, rehabilitation programs should be implemented in acute care and long term follow-up management to improve the functional outcomes. Spronk et al., (2018) recommended that both physical and psychological symptoms need attention months to years after the burn trauma.

\section{Conclusion:}

Self-care education was effective on improving quality of life and body image among burned patients.

\section{Recommendations:}

- Teaching booklet for burned patients especially for home care equipped with illustrations and pictures to improve quality of life should be available in burn departments.

- Other research should be done focusing on burns in exposed areas of the body

\section{References:}

- Abd Elalem, S., Shehata, O., \& Safaa, S., (2018): The effect of self-care nursing intervention model on self-esteem and quality of life among burn patients. Clinical Nursing Studies, 6(2): 79-90.

- Ardebili F, Bozorg Nejad M, \& Manzari ZS, (2016): Burn injury in Mottahari Burn Center in Tehran, Iran. World J Plast Surg; 5:77-9.

- Assiut burn center record, (2019)

- Coleman, E., Smith, J., Frank, J., Min, S., Parry, C., \& Kramer, A. (2014): Preparing patients and caregivers to participate in care delivered across settings: The care transitions intervention. Journal of the American Geriatrics Society, 52(11), 18171825. https://doi. Org/10.1111/j.15325415.2004.52504.x.

- Echevarría-Guanilo, M., Gonçalves, N., Farina., JA., \& Rossi, L., ( 2016): Assessment of healthrelated quality of life in the first year after burn Esc Anna Nery, 20(1):155-166.

- Elsherbiny OE, Salem MA, El-Sabbagh AH, Elhadidy MR, \& Eldeen SM, (2017): Quality of life of adult patients with severe burns. Burns. 2011; 37(5):776-89. [DOI:10.1016/j.burns.12.017] [ PMID]

- Faisal, A., Hussain, N., \& Jawed, H. (2015): Selfesteem in male and female patients of facial burn 
injuries in Karachi. Pakistan Business Review. 17(3).

- Hashemi F, Dolatabad FR, \& Yektatalab Sh, (2014): Effect of Orem self-care program on the life quality of burn patients referred to Ghotb-alDin-e-Shirazi Burn Center, Shiraz, Iran: A Randomized Controlled Trial. Int $\mathbf{J}$ Community Based Nurs Midwifery; 2(1): 46-48.

- Helen E., Diane B., Lesley S. \& Thomas B.y., (2017): Nursing management, burn, Lewis's Medical-Surgical Nursing, chapter (21), section (4), $4^{\text {th }}$ Ed, Australia and New Zealand Company, P. 463.

- Hinkle JL, \& Cheever KH, (2014): Brunner \& Suddarth Handbook of medical surgical nursing [T Najafi, M Zeynali, Persian trans.]. 13rded. Tehran: Jame'e Negar.

- Jafaryparvar Z, Adib M, Ghanbari Khanghah A, \& Kazem Nezhad Leyli E, ( 2018): Quality of Life and Associated Factors in Patients Suffering From Burns. J Holist Nurs Midwifery.; 28(3):179184. https://doi.org/10.29252/HNMJ.28.3.179

- Kildal M, Andersson G, Fugl-Meyer AR, Lannerstam K, \& Gerdin B, (2001): Development of a brief version of the Burn Specific Health Scale (BSHS-B). The Journal of trauma; 51(4):740-6.

- Li, L., Dai, J., Huang, Z., Pan, Q., Zhang, X., Jiang, M., \& Chen, Z. (2016): The effect of a rehabilitation nursing intervention model on improving the comprehensive health status of patients with hand burns. Burns $43877-885$.

- Mirzabeygi Gh, Givry A, (2011): [Burn nurse`s specialized duties (Per-sian)].

- Müller A, Smits D, Jasper S, Berg L, Claes L, \& Ipaktchi R, (2017): Validation of the German version of the Burn Specific Health Scale-Brief (BSHS-B). Burns: journal of the International Society for Burn Injuries; 49(6):13339.

- Orwelius, L., Willebrand, M., Gerdin, B., Ekselius, L., Fredrikson, M. \& Sjöberg, F.(2013): Long term health-related quality of life after burns is strongly dependent on pre-existing disease and psychological issues and less due to the burn itself. Burns 2(39); 229-235

- Ozdemir A., \& Saritas, S. (2018): Is the Quality of Life of Turkish Burn Patient's Family Affected During Acute Care? International Journal of Caring Sciences, 11 (2):997- 100.

- Pishnamazi Z, Rejeh N, Heravi-Karimooi M, \& Vaismoradi M, (2013): Validation of the Persian version of the Burn Specific Health Scale - Brief. Burns: journal of the International Society for Burn Injuries; 39(1):162-7.
- Pishnamazi Z, Kianiasiabar A, Heravi-Karimooi M, Zaeri F, \& Noorozza-deh R (2011): [Quality of life in burn patients (Persian)]. Payesh. 11(1):103-10.

- Pishnamazy Z, Kiani-Asiabar A, Heravi-\& Karimooi M, (2012): Quality of life in burn patients. Journal of Payesh; 11: 103-10.

- Roh YS, Seo CH, \& Jang KU, (2010): Effects of a skin rehabilitation-nursing program on skin status, depression, and burn-specific health in Burn survivors. Rehabil Nurs; 35: 65-9. Pmid: 20306614 https://doi.org/10.1002/j.20487940.2010.tb00033.x.

- Seyedoshohadaee M., Khachian A., Seyedfatemi, N., \& Mahmoudi. M (2019): The effect of shortterm training course by nurses on body image in patients with burn injuries. World J Plast Surgv.8(3): 359-364.

- Shahid, F., Ismail, M., \& Khan, S., (2018): Assessment of quality of life in post burn survivors: A cross-sectional single-center first validation study from Pakistan. Burns Open 2 (2018) 35-42.

- Spronk, I, Legemat, CM. Dokter, J., Loey, N., Baar, M., \& Polinder, S. (2018): Predictors of health-related quality of life after burn injuries: a systematic review. Critical Care, 22(160): 1-13.

- Stavrou D, Weissman O, Tessone A, Zilinsky I, Holloway S, Boyd J, \& Haik J, (2014): Health Related Quality of Life in burn patients - A review of the literature. Burns. 40(5):88-96

- Wasiak J, Lee SJ, Paul E, Mahar P, Pfitzer B, Spinks A, Cleland H6, \& Gabbe B, (2017): Predictors of health status and health-related quality of life 12 months after severe burn. Burns;40(4):568-74

- World Health Organization, Burns fact sheet, (2018): http:/www.who.int/ (Accessed January 2018).

- Zhang, X., Liu, Y., Deng, X., Deng, C., Pan, Y., \& Hu, A. (2019): The correlation between quality of life and acceptability of disability in patients with facial burn scars. Frontiers in Bioengineering and Biotechnology | www.frontiersin.org, 14, 1-7.

- Zorita LA, Blanes L, \& Daniela F, (2016): Health-related quality of life and self-esteem among burn patients. Wounds; 28(1): 27-34. 